EPRA International Journal of Economic and Business Review-Peer Reviewed Journal

Volume - 8, Issue -11, November 2020 |e-ISSN: 2347 - 9671| p- ISSN: 2349 - 0187

\title{
ADOPTION OF INFORMATION \& COMMUNICATION TECHNOLOGY AMONG THE STUDENTS AT TERTIARY LEVEL: BANGLADESH PERSPECTIVES
}

\begin{tabular}{|c|c|}
\hline Muhammad Abdus Salam ${ }^{*}$ & $\begin{array}{c}{ }^{1} \text { Department of Management Information Systems, } \\
\text { Noakhali Science and Technology University, }\end{array}$ \\
\hline Trisha Saha ${ }^{2,}$ & $\begin{array}{c}{ }^{2} \text { Department of Management Information Systems, } \\
\text { Noakhali Science and Technology University }\end{array}$ \\
\hline Tonmoy Dey & \\
& $\begin{array}{c}{ }^{3} \text { Department of Management Information Systems, } \\
\text { Noakhali Science and Technology University }\end{array}$ \\
\hline
\end{tabular}

"Corresponding Author

Information and Communication Technology (ICT) is extensively being used for educational purpose because it helps to make both learning and teaching effective and meaningful. Again, it shrinks the obstacles of habitual learning systems like allowing students to access unlimited educational resources and providing required data timely. Bangladesh has made marvelous betterment in this sector in the last couple of years especially in tertiary level. Now, it is high time to justify how the tertiary level students of Bangladesh are accepting ICT for learning. The study was conducted at the Noakhali Science and Technology University (NSTU) with randomly collected data from 250 students of various departments. It has justified the perceptions, behavior and expectations of tertiary level students towards the adoption of ICT. The results of this study are expected to be useful to the educational policymakers, institutions, educators and the relevant parties.

KEYWORDS: ICT Adoption, ICT in Education, Tertiary Education, NSTU, Bangladesh. 


\section{INTRODUCTION}

Education is a must for a society because without education it is impossible to ensure economic development and primary leverage (Assar, 2015). Assimilation of ICT into the education sector is one of the vital challenges in pedagogy for a long period of time (Juuti et al., 2009). Now a day's people are introducing with the modern technology more frequently and internet connection has become a fundamental need especially for metropolitan area (Rana \& Rana, 2020). In $21^{\text {st }}$ century Information \& Communication Technology, commonly acknowledged as ICT, is one of the most influential sources of gathering skills and knowledge. Computer based technologies and digital culture boost collaboration that made the world closer and influences on the people's life style such as how they live, learn and work. It is possible to evaluate the benefits of ICT accurately by an institution only when the ICT has been appropriately practiced and adopted in the education system of the institution (Chigona et al., 2010). The consequence of ICT is very influential in education sector both inside and outside the classroom setting particularly in tertiary level students (Basri et al., 2018). As an influential instrument, ICT should be used to enhance the educational aspiration like communication, collaboration, gathering and analyzing information and problem identification and mitigation, because these are significant for creating skills and knowledge (Drent \& Meelissen, 2008). Moreover, ICT allows students to learn in an independent, dynamic and productive way to facilitate the community and it also creates an influential research and pedagogical atmosphere (Volman \& van Eck, 2001). Again, it provides a variety of opportunities to formulate learning procedure as pleasant, work-oriented and up to date. It is possible to create and disseminate skills and knowledge more effectively and efficiently by using ICT tools. Chen and $\mathrm{Wu}$ (2020) Showed that Students learning efficiency is drastically improved by the integration of Information and communication technology and mathematics remedial instruction. Essential factors behind the assimilation of information and communication technology should be recognized and analyzed in the institution (Gellerstedt et al., 2018). In an institution the efficiency of ICT based learning may depend on various attributes such as the accessibility in equipment and resources, how the teachers and students are upheld in its utilization and the assessment of resources to the student's experiences (Al-Adwan \& Smedley, 2012). Students' use frequency and knowledge level regarding computer technology have been significant for ICT based learning both in the global and nationa arena.

In Bangladesh, the prospective of the ICT sector and its effects towards the economy is officially recognized from 1997 (Sultana \& Shahabul, 2018).
National ICT guideline of Bangladesh, which is articulated in the year of 2009 , focuses on the fundamental changes of curriculum and education systems where ICT would be an efficient apparatus (Babu \& Nath, 2017). Lately, Bangladeshi educational institutions, especially the tertiary level are focusing on the online based new normal education systems. Moreover, today's cyber based generation in Bangladesh is accustoming to digital lifestyle. Therefore, it was expected that the use of ICT can be a great opportunity to disseminate the knowledge among the students and develop the education. However, the goal of this study was to accumulate the findings and the essence from a review of momentous chunk of the literature with a view to determine the approaches and expectations of tertiary level students of Bangladesh towards adoption of information and communication technology. The expected outcome of this study will facilitate policymakers, educationist and the individuals those who are functioning in the relevant field. It will also be supportive to enhance the ICT based education system and scholastic performance in Bangladesh.

\section{LITERATURE REVIEW}

Quite a lot of benefits may retain by using ICT including sophisticated learning technologies, internet and digital devices like better elucidating on a subject, accessibility to the effective resources and ability to develop a participative learning system (Williams, 2008). George et al., (2020) addressed that ICT provides huge reimbursement to the students by allowing them getting access to the huge amount of study materials that are not available in their institution. Alabi (2016) and Chaputula (2012) have shown that infrastructural conditions have a strong and positive correlation with the adoption of information and communication technology. A number of researchers have found that insufficient ICT infrastructure and personal devices, costly and weak internet connection, poor socio-economic condition, inadequate ICT related resources, lack of effective ICT governance and policy and fragile education systems are the hindrance of the expansion of ICT based education systems in developing countries (Dawadi \& Shakya, 2016; Khan et al., 2012; Light, 2009; Parvin, 2013; Rana \& Rana, 2020). Lim et al., (2020) in their study on the acceptance of ICT for teaching in Bangladesh and Nepal based on 76 relevant documents, argued that Bangladesh and Nepal yet thrive to optimize the benefits of ICT in education sector. Several researchers recommended that the ICT infrastructure should be cost-effective and user friendly, training program should be arranged for the stakeholders including teachers, long term strategic plan should be taken for the appropriate adoption of ICT in learning sector 
(Bariu, 2020; Jana \& Maiti, 2020; Phutela \& Dwivedi, 2019; Teeroovengadum et al., 2017).

A study conducted by Paul and Lal (2018) investigating the adoption of ICT among the tertiary level students in India, showed that maximum of the students uses digital technology in their study purpose. A large number of tertiary level students in Bangladesh are obsessive to the internet (Karim \& Nigar, 2014; Soron \& others, 2015). On the other hand, study shows that being addicted to mobile phone technologies often have off-putting consequences among the students that's why it appears as a matter of debate among the specialists (Islam et al., 2019). In Bangladesh, adopting learning and pedagogical practices through ICT tools is newfangled notion (Nurul Mostafa Kamal, 2019). Consequently, a lot of studies has been done in several times from different aspects of ICT in education. However, an impeccable review of the literature affirms gaps yet to fill, particularly in terms of students' perceptions in Bangladesh. We have recognized that limited studies have investigated how the students are accepting ICT towards learning in Bangladesh. According to Zainal \& Zainuddin (2020), in future research would be conducted on the impact of ICT and students' perceptions within particular subject.

\section{METHODOLOGY 3.1 QUESTIONNAIRE DESIGN AND DATA COLLECTION}

A structured questionnaire including two parts was employed to collect data from the respondents using a survey method. The first part of the questionnaire was developed to collect the demographic data of the respondents. On the other hand, the second part of the questionnaire consists of 15 items and this section aimed at collecting the responses on measurement items. Items used in this study were adopted from different previous studies on the similar research topic. Items along with their sources are included in the appendix section. All the responses, in second part, were collected using a Five-Point Likert Scale ranging from 1 (strongly disagree) to 5 (strongly agree). With a view to obtaining our research objectives we have selected tertiary level students as our target population and students from various departments of Noakhali Science and Technology University (NSTU) were taken as our sample. We have sent the questionnaire randomly to 250 students of NSTU from various departments through online within April 2020 to May 2020 .

\subsection{DATA ANALYSIS}

At first, 41 unengaged data from 250 data were removed using standard deviation in Microsoft Excel. After that 209 cleaned data were imported to SPSS for further analysis. All of the data were then analyzed using frequency and percentage method with a view to justifying our assumption regarding ICT adoption in tertiary level of Bangladesh and the objective of our study. Several graphs and chart were used to represent the result of the analysis.

\section{RESULTS AND DISCUSSIONS 4.1 Demographic Information of the Respondents}

Table 01 represents the demographic information of the respondents and from the table it can be observed that majority percentage of the respondents was male with $54 \%$ in number and rest of the $46 \%$ was female students. Respondents of 21-25 age ranges are highest in number indicating that most of them were from regular graduation and post-graduation level.

Table 01: Summary of the respondents' demographic information

\begin{tabular}{|c|c|c|c|}
\hline \multicolumn{2}{|c|}{ Attributes } & Frequency & Percentage (\%) \\
\hline \multirow{3}{*}{ Gender } & Male & 113 & $54 \%$ \\
\cline { 2 - 4 } & Female & 96 & $46 \%$ \\
\hline \multirow{3}{*}{ Age } & $16-20$ & 18 & $9 \%$ \\
\cline { 2 - 4 } & $21-25$ & 172 & $82 \%$ \\
\cline { 2 - 4 } & $26-30$ & 19 & $9 \%$ \\
\hline
\end{tabular}

\subsection{Findings}

This part will represent the findings on 15 items used in our structured questionnaire on a measurement scale ranging from 1 (strongly disagree) to 5 (strongly agree). Findings on each item are represented in graphs and all the graphs are represented in the appendix ( $A$ : Graphical representation of the Findings). However, each of the findings are discussed below-

At first it was asked to the respondents that whether they find it trouble-free to learn using education related ICT tools or not. Figure 01 represents that $28 \%$ of the respondents remained neutral on that point. Successively, $26 \%$ and $23 \%$ of the respondents agreed and strongly agreed on this point indicating that the education related ICT tools are easy to learn. The scenario is almost similar in case of the ease of use of the education related ICT tools which can be seen in figure $\mathbf{0 2} .18 \%$ of the respondents remained neutral, $33 \%$ agreed, and $31 \%$ strongly agreed that education related ICT tools are easy to use. 
The percentage of respondents disagreeing on these two questions indicates that education related ICT tools are not much complex to learn and use. However, it was also asked to them that how they feel while interacting with available education related ICT tools. Majority of the respondents (see in figure 03) agreed that they are clear about the operational procedure of education related ICT tools available to them and they have understandings about the usage of those tools. The findings on that point indicates that ICT tools to support educational purposes are not so much complex to understand and operate. This finding justifies the previous findings ICT tools are not much complex to learn and use from the students' perspectives. If students are given proper opportunities, they can easily discover the ways in using the ICT tools for their education purposes. Although, it was obtained from our survey that students agreed that using education related ICT tools are easy and understandable. Nevertheless, there should be proper training session for the students for making them skilled at using education related ICT tools effortlessly because majority of them disagreed on that point that being skilled at using education related ICT tools effortless (see in figure 04).

Respondents were also asked some questions on the points of justifying the importance of ICT tools used for educational purposes and they replied very positively as anticipated. They were asked whether the education related ICT tools are beneficial or not, whether those tools enhance their academic productivity or not, whether those tools encourages good grades or not. From the figure 05, 06, 07 it can be observed that in almost all points they agreed positively. These indicate the universality of the importance of ICT in education once again.

In order to obtain some comparative data between conventional and e-learning methods, respondents were asked some questionnaires. On point that, whether conventional learning is better than e-learning or not we found some confusing replies from the respondents. Figure 08 represents the scenario- the number of respondents agreed are almost similar to the number of respondents disagreed and neutral responses are majority in percentage. Almost same findings can be observed for the next point (see in figure 09). Students were asked about the effectiveness of e-learning platform over traditional platform in case of students' performance assessment. Majority of the responses are found neutral. These findings are justification of that point that if education related ICT tools are made available among students then their primary perception on learning and assessment mode will be changed. Unless they are common to such tools for their everyday education related purposes, they will remain confusing on the battle of argument between e-learning and conventional learning platform although they agreed that ICT related tools are beneficial to their academic productivity and they are highly interested to use education related ICT tools in their academic arena (see in figure10).

On next points students agreed highly that they are able to use education related ICT tools as they believe they have the minimum basic knowledge and confidence for doing so. Figure 11 represents the case that majority of the respondents (33\% agreed, and 28\% strongly agreed) are confident enough that they have knowledge to run and use education related ICT tools. However, as anticipated, they lack proper resources for using such advanced and expensive educational tools (see in figure 12). In addition to that almost all of the agreed that owning these advanced tools are costly to them (see in figure 13). These two findings are the indication of the financial hurdles of the students at tertiary level.

Finally, institutional contributions were checked by asking them two questions. Replies on whether education related ICT tools and facilities provided by their institution are satisfactory for them or not indicates that students are less aware of that particular extent. Because from strongly disagree to strongly agree almost all clusters are of same value (see in figure 14). This means supports from their institute are perplexing in this extent. However, they are happy with the supports provided by their faculty members regarding the use of education related ICT tools indicating the willingness of the authority (see in figure 15).

\subsection{Discussion}

Findings of our study indicate some major insights regarding the adoption of ICT in tertiary level of education in Bangladesh. Students are highly motivated to use the education related ICT tools for their regular education purposes as they have acknowledged the benefits of these tools. They are confident enough to operate the tools for the betterment of their academic activities. They want to keep pace with the advanced world as well as the education system of the developed countries. However, they highlighted the lacking of adequate resources and expenses of owing these advanced tools. Moreover, need of increasing institutional supports are also highlighted. Government of Bangladesh is trying to cover up the overall tertiary level education system with huge investments in ICT as part of Vision 2021. Yet, the triumph is far from the reality. Respected authorities should ensure basic functioning tools for education. Training and financial facilities like- subsidies and tax-free purchase should be increased. Financial institutions should come up with student friendly EMI plans. Institutions should be more considerate while budgeting for institutional 
development keeping ICT based education facilities with highest priorities. Although, students may obtain huge benefits by using ICT tools in education but never would overlook conventional systems because several researches concluded that conventional pedagogy systems is more effective then ICT based education (Banerjee et al., 2007; Barrera-Osorio \& Linden, 2009; Bulman \& Fairlie, 2016; Comi et al., 2017). However, it is not possible to build up a developed nation ignoring ICT in education.

\section{IMPLICATIONS}

Findings of the study may contribute both theoretically and practically. Theoretically, it may help the future researchers who are interested to conduct research on the same or related topics. Moreover, policy maker and related authorities of education system of the government will get some insight from the findings. To them, the findings will be helpful in planning and executing any further projects and investment in ICT based education at tertiary level.

\section{CONCLUSION}

In the era of $21^{\text {st }}$ century, Information and Communication Technology (ICT) is one of the most influential factors affecting the development of education system. With the betterment of the education systems ICT is being adopted all over the world. This study focuses on how the students of Bangladesh, especially in tertiary level are adopting ICT for their education purposes. Most of the students' approaches positively towards ICT apart from a few issues like infrastructural facility, device cost, data charge etc. Even so, students trust and expectations leads to a positive approach to adopt with ICT. Proper financial supports and subsidies, dedicated budget, several training programs should be ensured to facilitate the orientation and adoption of education related ICT tools among the students of Bangladesh at tertiary level at a larger scale.

\section{LIMITATION AND FUTURE RESEARCH}

Although the study produces significant outcome, there might have some limitations like respondents are Tertiary level students. Therefore, overall state of country's ICT adoption in education sector cannot be justified with the same findings. Again, as the respondents are from same university, which is located in country side area, thus the study may not represent the actual outcome of urban area's student's perceptions. The study followed random sampling method but the numbers of response from all departments are not same. Future studies on similar topic may consider these issues.

\section{APENDIX A. Graphical Representation of the Findings}

Figure 01: Q.1: I find it trouble-free to learn using education related ICT tools.

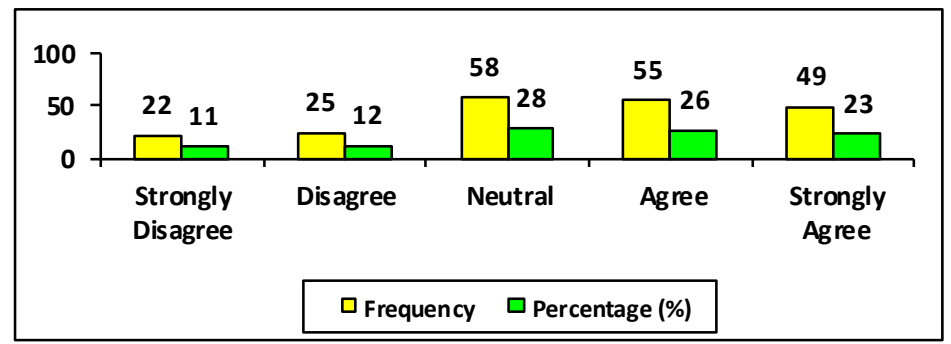

Figure 02: Q.2: I find it easier to use education related ICT tools.

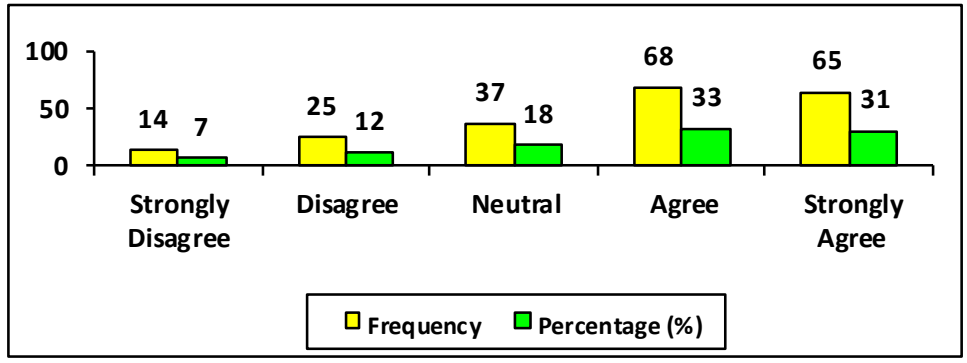


Figure 03: Q.3: My interaction with available education related ICT tools is apparent and understandable.

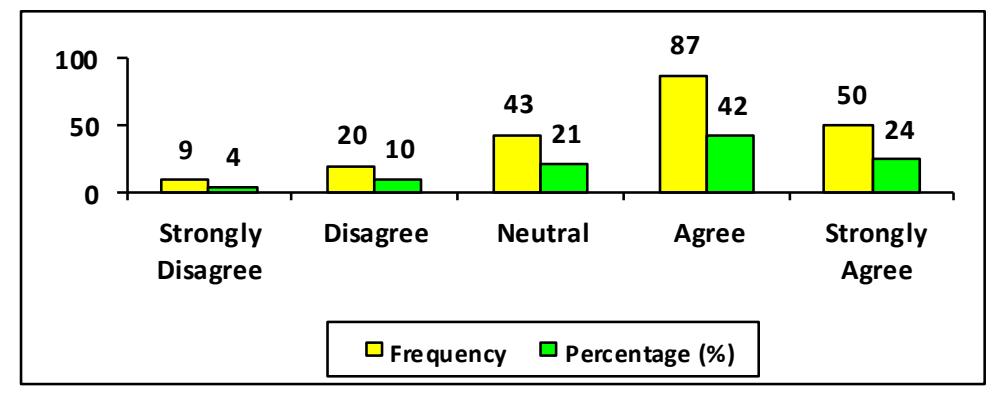

Figure 04: Q.4: Being skilled at using education related ICT tools is effortless.

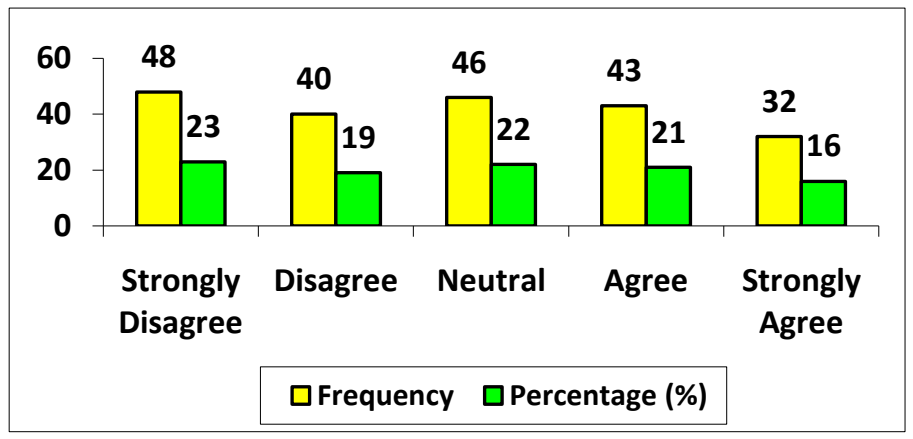

Figure 05: Q.5: Education related ICT tools are beneficial for my academic activities.

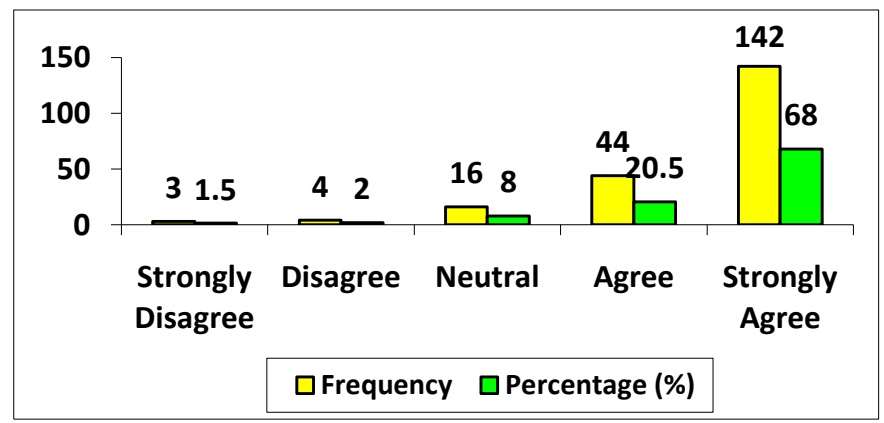

Figure 06: Q.6: Education related ICT tools enhance my productivity in academic activities.

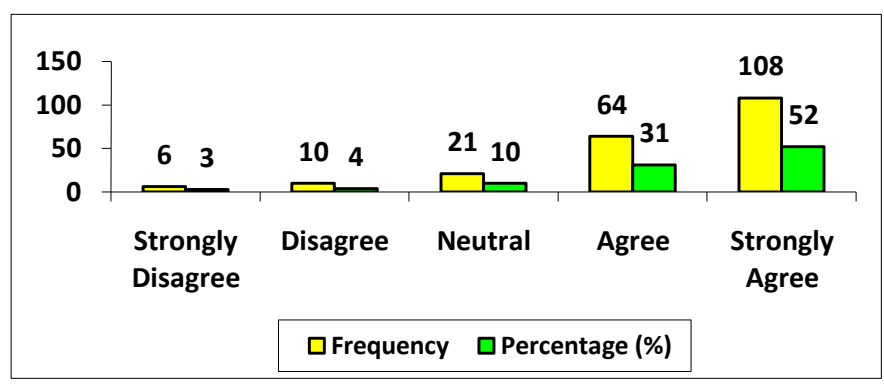

(c) 2020 EPRA JEBR | EPRA International Journal of Economic and Business Review ｜ www.eprajournals.com 
Figure 07: Q.7: Education related ICT tools are encouraging in ensuring good grades in academic arena.

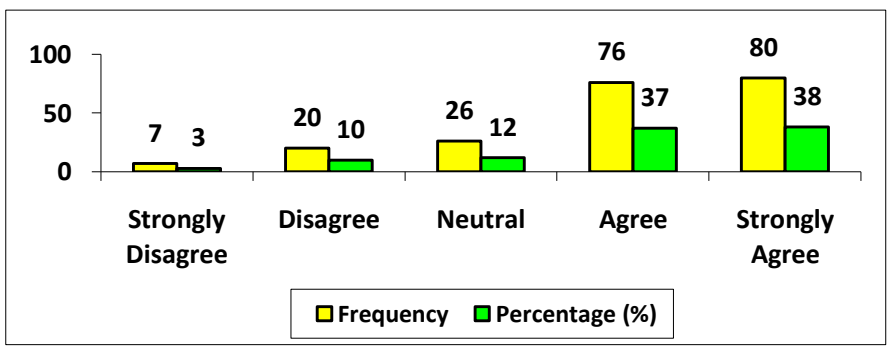

Figure 08: Q.8: E-learning is effective than conventional learning.

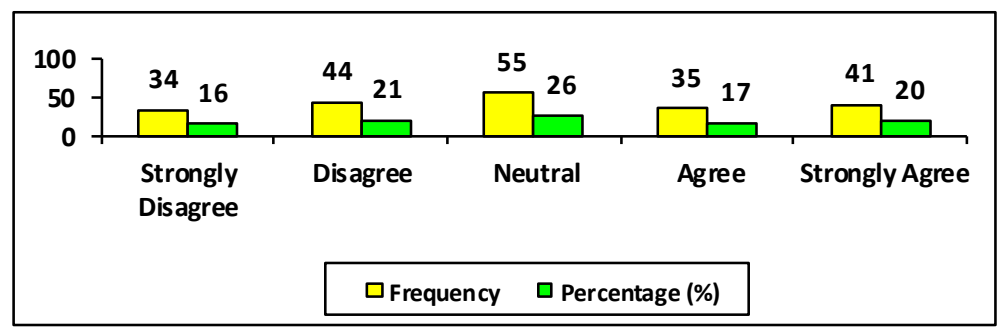

Figure 09: Q.9: Students performance assessment through e-learning platform is effective than through traditional learning.

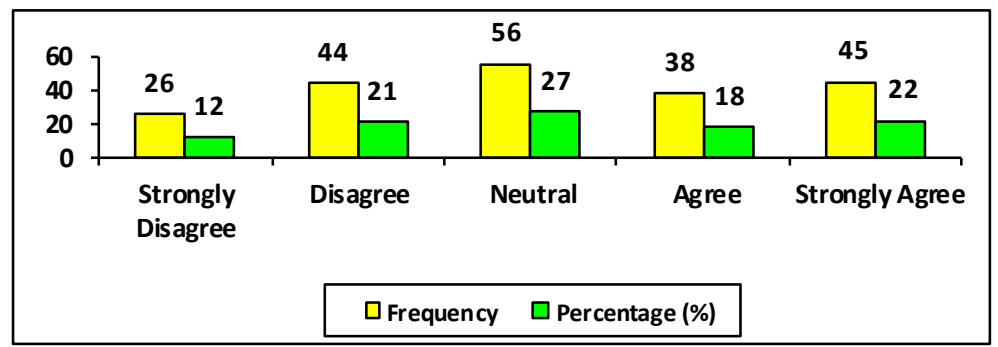

Figure 10: Q.10: I am interested in using education related ICT tools in my academic arena.

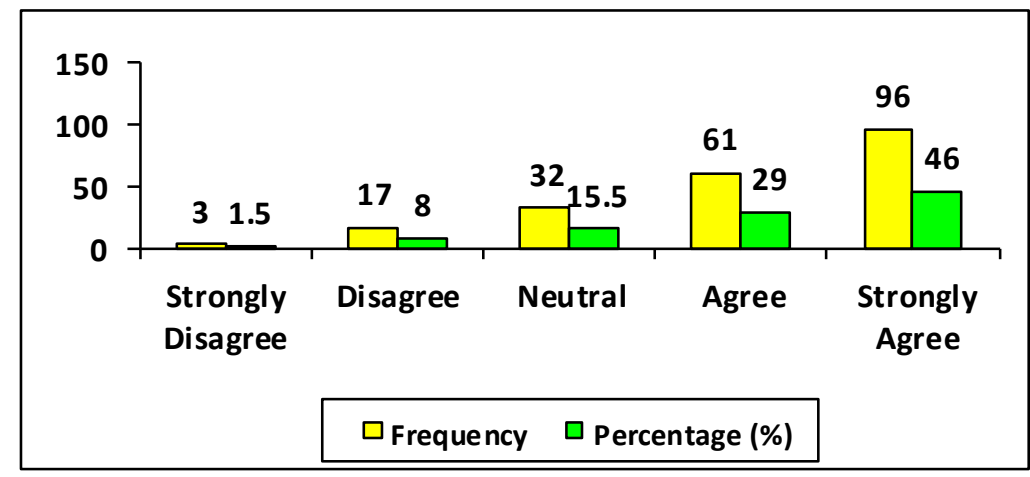

(c) 2020 EPRA JEBR ｜EPRA International Journal of Economic and Business Review ｜ www.eprajournals.com 
Figure 11: Q.11: I have adequate knowledge to use education related ICT tools.

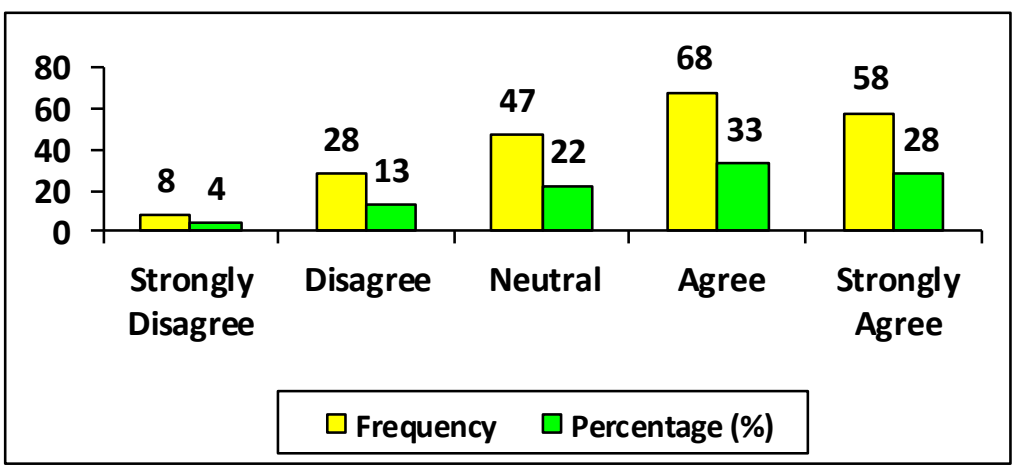

Figure 12: Q.12: I have adequate resources to use education related ICT tools.

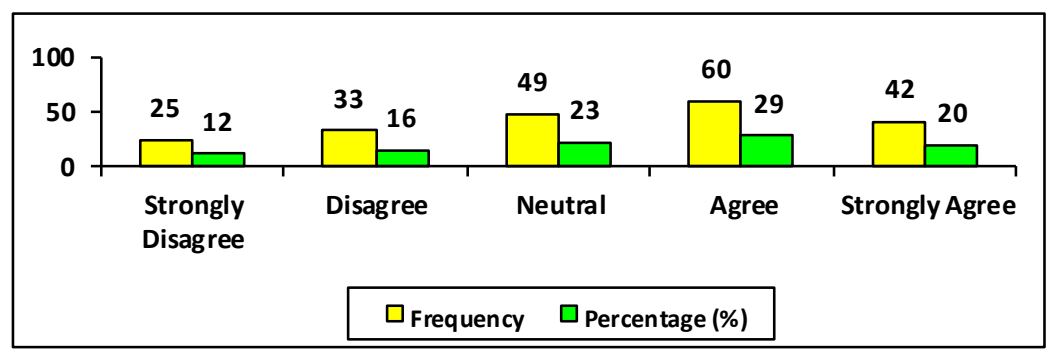

Figure 13: Q.13: I find education related ICT tools expensive to own.

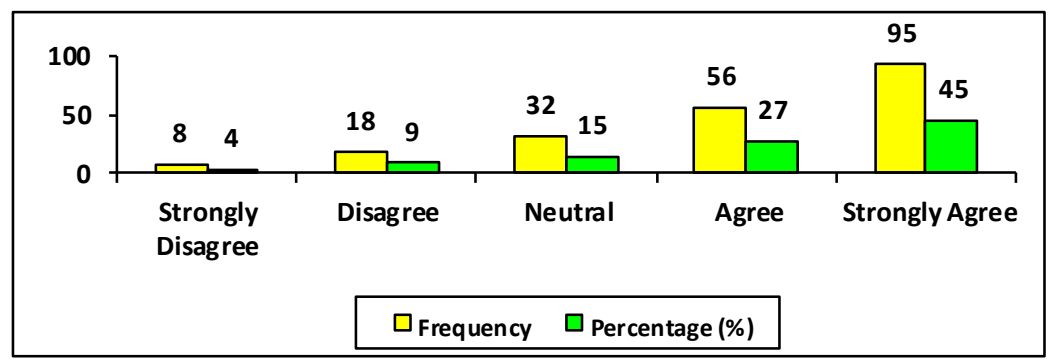

Figure 14: Q.14: Education related ICT tools and facilities provided by my institution are satisfactory for me

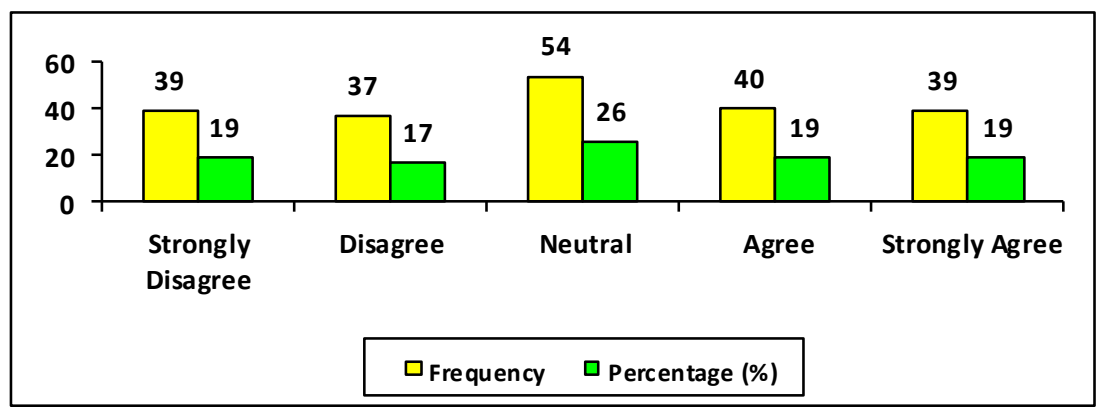


Figure 15: Q.15: Faculty members provide proper instructions regarding the use of education related ICT tools.

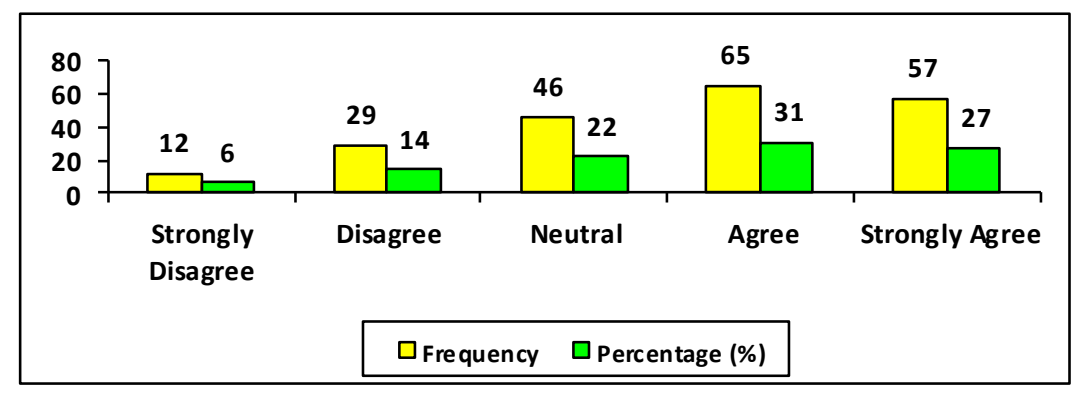

APENDIX B. Items with adopted Sources

\begin{tabular}{|c|c|c|}
\hline SL & Items & Sources \\
\hline 01 & I find it trouble-free to learn using education related ICT tools. & \multirow{15}{*}{$\begin{array}{l}\text { (Alabi, 2016; Assar, } \\
\text { 2015; Chen \& Wu, } \\
\text { 2020; Gellerstedt et } \\
\text { al., 2018; Islam et } \\
\text { al., 2019; Jana \& } \\
\text { Maiti, 2020; Obiri- } \\
\text { Yeboah et al., 2013; } \\
\text { Paul \& Lal, 2018) }\end{array}$} \\
\hline 02 & I find it easier to use education related ICT tools. & \\
\hline 03 & $\begin{array}{l}\text { My interaction with available education related ICT tools is apparent and } \\
\text { understandable. }\end{array}$ & \\
\hline 04 & Being skilled at using education related ICT tools is effortless. & \\
\hline 05 & Education related ICT tools are beneficial for my academic activities. & \\
\hline 06 & Education related ICT tools enhance my productivity in academic activities. & \\
\hline 07 & $\begin{array}{l}\text { Education related ICT tools are encouraging in ensuring good grades in } \\
\text { academic arena. }\end{array}$ & \\
\hline 08 & E-learning is effective than conventional learning. & \\
\hline 09 & $\begin{array}{l}\text { Students performance assessment through e-learning platform is effective } \\
\text { than through traditional learning. }\end{array}$ & \\
\hline 10 & I am interested in using education related ICT tools in my academic arena. & \\
\hline 11 & I have adequate knowledge to use education related ICT tools. & \\
\hline 12 & I have adequate resources to use education related ICT tools. & \\
\hline 13 & I find education related ICT tools expensive to own. & \\
\hline 14 & $\begin{array}{l}\text { Education related ICT tools and facilities provided by my institution are } \\
\text { satisfactory for me. }\end{array}$ & \\
\hline 15 & $\begin{array}{l}\text { Faculty members provide proper instructions regarding the use of education } \\
\text { related ICT tools. }\end{array}$ & \\
\hline
\end{tabular}

\section{REFERENCES}

1. Al-Adwan, A., \& Smedley, J. (2012). Implementing e-learning in the Jordanian Higher Education System: Factors affecting impact. International Journal of Education and Development Using ICT, 8(1).

2. Alabi, O. O. (2016). Adoption of Information and Communication Technologies (ICTs) by Agricultural Science and Extension Teachers in Abuja, Nigeria. Journal of Agricultural Education, 57(1), 137-149.

3. Assar, S. (2015). Information and Communications Technology (ICT) and Education. International Encyclopedia of the Social \& Behavioral Sciences, 66-71.

4. Babu, R., \& Nath, S. R. (2017). Use of ICT in secondary education in Bangladesh: Policies and practices. Asian Network of Training and Research Institutions in Educational Planning, 23(1), 5-6.

5. Banerjee, A. V, Cole, S., Duflo, E., \& Linden, L. (2007). Remedying education: Evidence from two randomized experiments in India. The Quarterly Journal of Economics, 122(3), 1235-1264.

6. Bariu, T. N. (2020). Status of ICT Infrastructure Used in Teaching and Learning in Secondary Schools in Meru County, Kenya. European Journal of Interactive Multimedia and Education, 1(1), e02002.

7. Barrera-Osorio, F., \& Linden, L. L. (2009). The use and misuse of computers in education: evidence from a randomized experiment in Colombia. The World Bank. 
8. Basri, W. S., Alandejani, J. A., \& Almadani, F. M. (2018). ICT adoption impact on students' academic performance: Evidence from Saudi universities. Education Research International, 2018.

9. Bulman, G., \& Fairlie, R. W. (2016). Technology and education: Computers, software, and the internet. In Handbook of the Economics of Education (Vol. 5, pp. 239-280). Elsevier.

10. Chaputula, A. H. (2012). State, adoption and use of ICTs by students and academic staff at Mzuzu University, Malawi. Program.

11. Chen, C.-L., \& Wu, C.-C. (2020). Students' behavioral intention to use and achievements in ICT-Integrated mathematics remedial instruction: Case study of a calculus course. Computers \& Education, 145, 103740.

12. Chigona, A., Chigona, W., Kausa, M., \& Kayongo, P. (2010). An empirical survey on domestication of ICT in schools in disadvantaged communities in South Africa. International Journal of Education and Development Using ICT, 6(2), 21-32.

13. Comi, S. L., Argentin, G., Gui, M., Origo, F., \& Pagani, L. (2017). Is it the way they use it? Teachers, ICT and student achievement. Economics of Education Review, 56, 24-39.

14. Dawadi, B. R., \& Shakya, S. (2016). ICT implementation and infrastructure deployment approach for rural Nepal. In Recent Advances in Information and Communication Technology 2016 (pp. 319-331). Springer.

15. Drent, M., \& Meelissen, M. (2008). Which factors obstruct or stimulate teacher educators to use ICT innovatively? Computers \& Education, 51(1), 187199.

16. Gellerstedt, M., Babaheidari, S. M., \& Svensson, L. (2018). A first step towards a model for teachers' adoption of ICT pedagogy in schools. Heliyon, 4(9), e00786.

17. George, T. O., Orbih, M. U., Olonade, O., Onwumah, A., \& Olaonipekun, T. (2020). PERSONAL LEARNING OBSTACLES AND THE ADOPTION OF ICT AMONG FEMALE STUDENTS IN SELECTED PUBLIC SECONDARY SCHOOLS IN OGUN STATE, NIGERIA. Proceedings of SOCIOINT, 2020(7th).

18. Islam, M. S., Karia, N., Khaleel, M., Khalid, J., Al Mamun, M. A., Bhuiyan, M. Y. A., \& Fouji, M. H. (2019). From ICT adoption to ICT addiction: What really matters between the use of ICT and learning performance? " International Journal of Electronic Commerce Studies, ” 9(2), 133-159.

19. Jana, S. K., \& Maiti, A. (2020). Innovations in Higher Education in India. In Theoretical and Practical Approaches to Innovation in Higher Education (pp. 162-183). IGI Global.

20. Juuti, K., Lavonen, J., Aksela, M., Meisalo, V., \& others. (2009). Adoption of ICT in science education: A case study of communication channels in a teachers' professional development project. Eurasia Journal of Mathematics, Science \& Technology Education.

21. Karim, A. K. M. R., \& Nigar, N. (2014). The internet addiction test: Assessing its psychometric properties in Bangladeshi culture. Asian Journal of Psychiatry, 10, 75-83.

22. Khan, M., Hossain, S., Hasan, M., \& Clement, C. $K$. (2012). Barriers to the Introduction of ICT into Education in Developing Countries: The example of Bangladesh. Online Submission, 5(2), 61-80.

23. Light, D. (2009). The role of ICT in enhancing education in developing countries: Findings from an evaluation of the Intel teach essentials course in India, Turkey, and Chile. Journal of Education for International Development, 4(2), 52-66.

24. Lim, C. P., Ra, S., Chin, B., \& Wang, T. (2020). Leveraging information and communication technologies (ICT) to enhance education equity, quality, and efficiency: case studies of Bangladesh and Nepal. Educational Media International, 57(2), 87-111.

25. Nurul Mostafa Kamal, Z. (2019). ICT in Education for Effective and Creative Teaching: Bangladesh Policies and ICT Integration in Education. Education for Effective and Creative Teaching: Bangladesh Policies and ICT Integration in Education (April 6, 2019).

26. Obiri-Yeboah, K., Kwarteng, K. O., \& Kyere-Djan, $R$. (2013). Factors affecting ICT adoption in tertiary institutions in Ghana: A case of Kwame Nkrumah University of Science and Technology. Information and Knowledge Management, 3(6), 13-21.

27. Parvin, S. (2013). Integrations of ICT in education sector for the advancement of the developing country: Some challenges and recommendationsBangladesh perspective. International Journal of Computer Science \& Information Technology, 5(4), 81.

28. Paul, S., \& Lal, K. (2018). Adoption of Digital Technologies in Tertiary Education: Evidence From India. Journal of Educational Technology Systems, 47(1), 128-147.

29. Phutela, N., \& Dwivedi, S. (2019). Impact of ICT in Education: Students' Perspective. Proceedings of International Conference on Digital Pedagogies (ICDP).

30. Rana, K., \& Rana, K. (2020). ICT Integration in Teaching and Learning Activities in Higher Education: A Case Study of Nepal's Teacher Education. Malaysian Online Journal of Educational Technology, 8(1), 36-47.

31. Soron, T. R., \& others. (2015). Successful management of Facebook addiction in Bangladesh: A case report. Journal of Psychiatry, 18(2), 1000247.

32. Sultana, M., \& Shahabul, H. M. (2018). The Cause of Low Implementation of ICT in Education Sector Considering Higher Education: A Study on Bangladesh. Canadian Social Science, 14(12), 6773 .

33. Teeroovengadum, V., Heeraman, N., \& Jugurnath, B. (2017). Examining the antecedents of ICT adoption in education using an extended technology acceptance model (TAM). International Journal of 
Education and Development Using ICT, 13(3).

34. Volman, M., \& van Eck, E. (2001). Gender equity and information technology in education: The second decade. Review of Educational Research, 71(4), 613-634.

35. Williams, P. (2008). Leading schools in the digital age: A clash of cultures. School Leadership and Management, 28(3), 213-228.

36. Zainal, A. Z., \& Zainuddin, S. Z. (2020). Technology adoption in Malaysian schools: An analysis of national ICT in education policy initiatives. Digital Education Review, 37, 172-194. 